\title{
Adrenal steroid type I and type II receptor binding: estimates of in vivo receptor number, occupancy, and activation with varying level of steroid
}

\author{
Robert L. Spencer ${ }^{1}$, Elizabeth A. Young ${ }^{2}$, Phillip H. Choo ${ }^{1}$ and Bruce S. McEwen ${ }^{1}$ \\ ${ }^{1}$ The Rockefeller University, New York, NY 10021 (U.S.A.) and ${ }^{2}$ Department of Psychiatry, Mental Health Research Institute, University of \\ Michigan, Ann Arbor, MI 48109 (U.S.A.)
}

(Accepted 12 September 1989)

Key words: Glucocorticoid receptor; Corticosterone; Dexamethasone; Brain; Hippocampus; Pituitary; Rat

\begin{abstract}
Adrenal steroid (AS) receptors differ from other steroid receptors in the inability of the activated form of the cytosolic receptor to exchange ligand in an in vitro binding assay. We extended this finding by demonstrating that AS receptors extracted from isolated brain nuclei also failed to exchange ligand. Taking advantage of this unique feature of AS receptors, we measured type I and type II AS binding level in rats with varying amounts of endogenous glucocorticoids or exogenous dexamethasone (DEX). We estimated the degree of receptor occupation/ activation in various brain areas and the pituitary during basal glucocorticoid conditions and after acute stress. There was a variable proportion of type I receptors in the hippocampus which were unactivated during basal conditions $(0-35 \%)$. The proportion of unactivated type I receptors increased (55-65\%) after DEX treatment. The hippocampus was especially sensitive to the ability of low basal corticosterone (CORT) levels to activate both type I and type II receptors, whereas the pituitary was very insensitive, evidenced by a failure of acute stress levels of endogenous glucocorticoids to occupy/activate type II receptors in the pituitary. Comparison of estimates of the degree of in vivo hippocampal type I and type II receptor activation for the various treatment groups with estimates of in vitro type I and type II receptor occupation by steroid suggested that DEX was more efficient than CORT in producing or maintaining the activated form of the type II receptor in vivo, whereas CORT was more efficient than DEX in activating the type I receptor. These studies suggest that AS receptors in the brain, and especially the hippocampus, are more sensitive to circulating levels of glucocorticoids than the pituitary. There also may be a greater capacity for physiological variations in type I receptor occupation in vivo than had previously been suggested. Finally, discrepancies between CORT and DEX affinity in vitro for type I and type II sites and their in vivo potency may be accounted for by differences in the ability of these compounds to activate type I and type II AS receptors.
\end{abstract}

\section{INTRODUCTION}

Receptors for adrenal steroids (AS) are found in cells throughout the body, including the brain. Two separate, high-affinity receptors for AS have been characterized by receptor binding studies ${ }^{27,41}$, and recently cDNA clones corresponding to the genes for these two receptors have been isolated and sequenced ${ }^{1,14}$. One receptor, type $I$, has a high affinity ( $K_{\mathrm{d}}=1 \mathrm{nM}$ or less) for both the mineralocorticoid, aldosterone, and the glucocorticoids, cortisol and corticosterone (CORT), and a 3- to 5-fold lower affinity for the synthetic glucocorticoid, dexamethasone $(\mathrm{DEX})^{2,27,36}$. The second receptor, type II, has a high affinity for DEX $\left(K_{\mathrm{d}}\right.$ less than $\left.1 \mathrm{nM}\right)$, a 3- to 5-fold lower affinity for CORT, and 10- to 20-fold lower affinity for aldosterone $\mathrm{e}^{27,41}$.

Within the brain there is regional variation in the density of both the type I and type II AS receptors, which is paralleled by the concentration of their respective mRNA $^{7}$. The density of type II receptors is more uniform than the type $I$ receptor and in most brain regions is about 10 times higher in concentration than the type $I$ receptor. The hippocampal-septal system stands out as having exceptionally high concentrations of the type $I$ receptor and in the hippocampus approaches almost 50\% of the concentration of the type II receptor ${ }^{4}$.

The presence of AS receptors in the brain confers on the brain the ability to detect and respond to varying levels of glucocorticoids. The response of the brain to glucocorticoids may be modified by changes in AS receptor number. A decrease of AS receptors in rat brain has been reported after glucocorticoid treatment, chronic stress, or in aged rats ${ }^{31,33,39}$. Diurnal variations in AS receptor number have also been found ${ }^{7,28}$.

Prevailing models of steroid receptor action propose that the receptor, when bound by steroid, undergoes a conformational change, referred to as activation or transformation ${ }^{23,42}$. The activated form of the receptor has a high affinity for DNA and is found exclusively in the nucleus, whereas the unactivated form of the receptor

Correspondence: R.L. Spencer, The Rockefeller University, Box 290, 1230 York Ave., New York, NY 10021, U.S.A. 
has a much lower affinity for DNA and either resides in the extranuclear cytosolic compartment and translocates to the nucleus upon activation or resides in the nucleus but 'leaks' into the cytosol during tissue homogenization $^{12,42}$. The AS type II receptor, and perhaps also the type I receptor, are unique from other steroid receptors, in that only the unactivated form of the cytosolic receptor can rebind steroid and participate in an in vitro exchange assay9. Thus, the obtained $B_{\max }$ for type I or type II receptor binding indicates only the number of unactivated receptors present in the cytosol pool. Consequently, studies of cytosolic AS receptor binding have routinely been conducted on rats which were adrenalectomized in order to eliminate the presence of endogenous CORT and subsequent receptor activation.

In this study we use this unique feature of AS receptor binding to evaluate the level of receptor occupation and activation in various brain regions and pituitary during manipulations of endogenous and exogenous steroid levels. We have examined both type I and type II AS receptor binding for intact rats at the nadir of their CORT circadian cycle. In addition, the level of endogenous CORT (the primary glucocorticoid in the rat) at the time of sacrifice was elevated in some rats by exposing them to acute stress, reduced in others by administering to them a drinking water solution containing $\mathrm{DEX}^{29,35}$, and eliminated in others by $16 \mathrm{~h}$ adrenalectomy (ADX). We have also examined the receptor binding in each condition across a range of radioligand concentrations rather than at a single saturating concentration so that we can estimate the amount of competing steroid present in the cytosol (determined by the degree of shift in $K_{\mathrm{d}}$ ) as well as the maximum number of binding sites $\left(B_{\max }\right)$. We also report here the results of our attempts to measure in an in vitro exchange assay specific binding of extracted AS receptor protein from isolated nuclei.

\section{MATERIALS AND METHODS}

\section{Animals}

For each experiment animals were male Sprague-Dawley rats (175-250 g). Animals were housed in hanging wire mesh cages (3 per cage) in an animal room separate from the laboratory. The animal room was maintained on a 14:10 day-night cycle with lights on at $05.00 \mathrm{~h}$. The animals were given rat chow and tap water ad libitum, except after ADX, in which case $0.9 \%$ saline was substituted for tap water.

\section{Steroids}

$\left[1,2,6,7-{ }_{-3}^{3} \mathrm{H}(\mathrm{N})\right]$ Corticosterone $(112 \mathrm{Ci} / \mathrm{mmol})$ and $\left[6,7-{ }^{3} \mathrm{H}(\mathrm{N})\right]$ dexamethasone $(39-50 \mathrm{Ci} / \mathrm{mmol})$ were obtained from New England Nuclear (Boston, MA). $\left[1,2-{ }^{3} \mathrm{H}(\mathrm{N})\right]$ Aldosterone $(75 \mathrm{Ci} / \mathrm{mmol})$ was obtained from Amersham (Arlington Heights, IL). Unlabeled CORT was obtained from Steraloids (Wilton, NH) and DEX from Sigma (St. Louis, MO). The selective type II receptor agonist, RU26988, was a gift from Roussel-Uclaf (Romainville, France).

\section{Adrenalectomy}

Bilateral adrenalectomy was performed on animals fully anesthetized with the inhalant, Metofane (Pitman-Moore, Washington Crossing, NJ). Aseptic surgical procedure was used.

\section{Experiment 1}

In the first experiment we compared the levels of type I and type II AS receptor binding in $16 \mathrm{~h}$ ADX and intact unstressed or stressed rats. The 3 treatment groups were designated as $\mathrm{ADX}$, intact/no-stress and intact/stress. There were 3 rats per group and the experiment was repeated on 3 separate occasions. The intact/no-stress rats were killed at either 07.00 or $09.00 \mathrm{~h}$ in the room in which they were housed. The ADX and intact/stress rats were transferred at $09.00 \mathrm{~h}$ to portable cages, placed on a cart and transported to a room on a different floor, where they were killed $30 \mathrm{~min}$ later. The intact/stress rats had no experimentally induced stress in this experiment other than that resulting from handling and transport and they did not differ from the ADX rats in that regard other than their exposure to an elevation of endogenous CORT. Rats were decapitated and trunk blood was collected for serum CORT determinations. Brains were removed, dissected on ice and tissue rapidly frozen and stored at $-80^{\circ} \mathrm{C}$ for subsequent binding studies.

\section{Experiment 2}

In the second experiment we repeated the basic procedure of the first experiment, but included groups of $16 \mathrm{~h} \mathrm{ADX}$ rats and intact/no-stress rats which were given DEX in their drinking water $(1.5 \mu \mathrm{g} / \mathrm{ml})$ for $16 \mathrm{~h}$ prior to sacrifice. The five treatment groups were designated as ADX, ADXDEX, intact/no-stress, intact/stress and intact/DEX. The primary purpose of the DEX treatment was to see if the suppression of endogenous CORT levels by the DEX treatment would result in a higher detectable level of type I binding in the intact rat. The stress procedure in this experiment was modified. As in the first experiment, the intact/stress rats were transported to a room on a different floor from their home cage. They were then given, in addition, $1 \mathrm{~h}$ of restraint stress (plexiglass restrainers) from 08.00 to $09.00 \mathrm{~h}$ and were decapitated immediately after restraint. The intact/no-stress and intact/DEX rats were killed at $07.30 \mathrm{~h}$ in their home room. The ADX and ADX/DEX rats were also transported to another room and killed between 08.00 and $09.00 \mathrm{~h}$. As in the first experiment, there were 3 rats per treatment group, and the experiment was repeated on 3 separate occasions. Type I binding was measured with both $\left[{ }^{3} \mathrm{H}\right] \mathrm{DEX}$ and $\left[{ }^{3} \mathrm{H}\right]$ aldosterone in order to compare the adequacy of both ligands for measuring type I binding in vitro. On one occasion type I and type II single point binding of individual hypothalamus, cortex, cerebellum and pooled pituitary was examined for the 3 treatment groups, ADX, intact/no-stress and intact/stress. The data were combined with the single point values for the same brain areas and treatments obtained in Expt. 1.

\section{Experiment 3}

The third experiment examined the effect of increased duration and dose of DEX treatment on receptor binding. Groups of intact rats, 3 or 4 per group, were given DEX $(1 \mu \mathrm{g} / \mathrm{ml})$ in their drinking water for either 1,2 or 3 days or a higher dose of $\operatorname{DEX}(5 \mu \mathrm{g} / \mathrm{ml})$ in the drinking water for 3 days. The drinking water was not removed prior to time of sacrifice. A group of $16 \mathrm{~h}$ ADX rats was included for comparison.

\footnotetext{
Experiment 4

The procedure and treatment groups in the 4 th experiment were the same as the second experiment except that the dose of DEX in the drinking water was increased to $15 \mu \mathrm{g} / \mathrm{ml}$. There were 3 rats per group and the experiment was performed only once.

\section{Binding assay}

Tissue was homogenized ( 15 strokes at $1000 \mathrm{rpm}$ ) with a motordriven Teflon pestle and glass tube on ice and then centrifuged (Beckman Ultracentrifuge) at $105,000 \mathrm{~g}$ for $60 \mathrm{~min}$ at $4{ }^{\circ} \mathrm{C}$. The supernatant/cytosol was then added to incubation solutions containing radiolabeled steroids with or without unlabeled competitors. Cytosol
} 
was incubated at $4{ }^{\circ} \mathrm{C}$ with steroids overnight (18-22 h). Columns containing $1.25 \mathrm{ml}$ of LH-20 Sephadex (Pharmacia) were used to separate bound from free steroid. The eluate containing bound steroid was collected directly into scintillation vials. Scintillation fluor (Liquiscint) was added to the vials and tritium radioactivity counted on a scintillation counter (Packard Series 1599 Tri-Carb, 45\% efficiency).

The homogenization and incubation buffer (TEGMD) was comprised of $10 \mathrm{mM}$ Tris, $1 \mathrm{mM}$ EDTA, $20 \mathrm{mM}$ molybdic acid, $5 \mathrm{mM}$ dithiothreitol and $10 \%$ glycerin in double distilled water $(\mathrm{pH}=7.4)$. Pooled hippocampi were homogenized in buffer $(2.2 \mathrm{ml} /$ hippocampus $)$ yielding a final protein concentration of $1.0-1.3 \mathrm{mg}$ protein $/ \mathrm{ml}$ cytosol. Tissues from other brain regions were homogenized in a volume of 1.5 $\mathrm{ml}$ buffer, yielding a final protein concentration of $0.5-1.5 \mathrm{mg}$ protein $/ \mathrm{ml}$ cytosol. Type II binding was derived from the binding of $\left[{ }^{3} \mathrm{H}\right] \mathrm{DEX}$ with or without the presence of the selective type II competitor, RU26988 $(0.5 \mu \mathrm{M})^{22}$. See tables and figure legends for specific radioligand concentrations used in each experiment. Type I binding was determined from the binding of $\left[{ }^{3} \mathrm{H}\right] \mathrm{DEX}$ or $\left[{ }^{3} \mathrm{H}\right]-$ aldosterone in the presence of RU26988 $(0.5 \mu \mathrm{M})$. Binding in the presence of an excess of CORT $(2.5 \mu \mathrm{M})$ was used for determining non-specific binding. Non-specific binding was reliably less than $5 \%$ of total binding. For saturation binding assays, five different concentrations of radiolabeled ligand were used, and for single point binding assays a single saturating concentration of radiolabeled ligand was used. Specific binding was expressed as $\mathrm{fmol} / \mathrm{mg}$ of cytosol protein. Protein content was determined by the method of Bradford ${ }^{3}$, with use of bovine serum albumin (BSA) as a standard.

We have found that in vitro, $\left[{ }^{3} \mathrm{H}\right] \mathrm{DEX}$ is an effective radioligand for measuring type I AS receptors. Saturation binding of $\left[{ }^{3} \mathrm{H}\right] \mathrm{DEX}$ (in the presence of $0.5 \mu \mathrm{M}$ RU26988) to type I receptors in hippocampal cytosol from ADX rats resulted in a surprisingly low mean \pm S.E.M. $K_{\mathrm{d}}$ of $1.22 \pm 0.12 \mathrm{nM}(n=10)$ which was only 2 -fold higher than that obtained with $\left[{ }^{3} \mathrm{H}\right]$ aldosterone binding in the presence of $0.5 \mu \mathrm{M}$ RU26988 ( $0.69 \pm 0.07 \mathrm{nM}, n=7)$. Furthermore, competition studies which compared the $\mathrm{IC}_{50}$ for a number of steroids on $\left[{ }^{3} \mathrm{H}\right] \mathrm{DEX}$ or $\left[{ }^{3} \mathrm{H}\right]$ aldosterone binding of hippocampal cytosol from ADX rats (in the presence of $0.5 \mu \mathrm{M} \mathrm{RU} 26988$ ), resulted in an identical rank order of potency and a Pearson $r$, correlation coefficient, of 0.93 . The rank order potency of competing steroids was as follows: RU26752 > aldosterone, CORT, deoxycorticosterone $>$ cortisol $>$ progesterone, cortexolone, DEX $>$ 17- $\alpha$-progesterone $>11$-dehydroxy-corticosterone.

\section{Nuclear isolation and exchange assay}

An attempt was made to use an exchange assay to measure AS receptor extracted from isolated nuclei. This was based on the procedure routinely used for measuring estrogen receptor ${ }^{30}$. If successful, the procedure would allow for determination of receptor that was occupied and activated and would eliminate the requirement of ADX for making estimates of receptor number.

Rats were ADX several days in advance of the experiment. On the day of the experiment rats were treated with 1 of 4 injection conditions; a low dose of radiolabeled $\left[{ }^{3} \mathrm{H}\right] \mathrm{CORT}(150 \mu \mathrm{Ci}$ in $0.9 \%$ saline, i.m. $)$, a similar dose of unlabeled CORT ( $0.5 \mu \mathrm{g}$ in $0.9 \%$ saline, i.m. $)$, a high dose of CORT $(50 \mathrm{mg} / \mathrm{kg}$ in sesame oil, s.c.), or a control injection of sesame oil $(1 \mathrm{ml} / \mathrm{kg}$, s.c.). The radiolabelled steroid was given i.m. instead of the more traditional s.c. route in order to increase the rate of uptake. The ADX group given sesame oil provided a negative control group from which we expected no nuclear localization of AS receptors, whereas with low and high CORT treatment we expected moderate to high levels of AS receptors in the nuclear extract. The injection of $\left[{ }^{3} \mathrm{H}\right] \mathrm{CORT}$ to one group of rats provided for an estimate of the number of AS receptors in the nuclear extract from rats with low CORT treatment. One hour after injection rats were killed and brains were rapidly removed on ice and nuclei were isolated from either whole brain or in some cases from specific brain regions according to the procedure described previously ${ }^{44}$. Nuclear proteins were extracted with the addition of $0.6 \mathrm{M} \mathrm{KCl}$. The isolated nuclei were suspended twice in $1.5 \mathrm{ml}$ TEGMD buffer containing $0.6 \mathrm{M} \mathrm{KCl}$ and centrifuged for 10 $\min$ at $850 \mathrm{~g}$ and the resulting supernatant collected and pooled for each sample. Aliquots of the sample from rats given an injection of radiolabeled CORT were either directly mixed with scintillation cocktail and radioactivity counted in a scintillation counter or were first incubated with or without an excess of unlabeled CORT $(2.5 \mu \mathrm{M})$ and then radioactivity of bound steroid (separated from free using LH-20 Sephadex columns as described above) was counted. Nuclear extracts from the other treatment groups were added to exchange assay incubation vials. Binding of $\left[{ }^{3} \mathrm{H}\right] \mathrm{CORT}(1 \mathrm{nM})$ was examined in the exchange assay. Unlabeled CORT $(2.5 \mu \mathrm{M})$ was used to determine non-specific binding. DNA content of nuclear pellets was determined by the method of Burton'.

\section{CORT measuremen}

Serum CORT was measured by radioimmunoassay using rabbit antiserum raised against CORT-21-hemisuccinate BSA (B21-42, Endocrine Sciences, Tarzana, CA). Assay sensitivity was $10 \mathrm{pg}$ of CORT, and coefficients of variation within and between assays were $4 \%(n=$ $3)$ and $8 \%(n=7)$, respectively.

\section{Data analysis and statistics}

For saturation binding studies the binding parameters, dissociation constant $\left(K_{\mathrm{d}}\right)$ and binding maximum $\left(B_{\max }\right)$, were derived from Scatchard analysis ${ }^{17}$. Analysis of variance was used for testing overall differences between treatment groups for the various dependent measures. The Newman-Keuls test (or Tukey test, in the case of unequal group size) was used for tests of significant differences between specific means. Changes in binding levels are reported relative to the binding level of the $16 \mathrm{~h}$ ADX rats in that particular experiment. Data are expressed as mean \pm S.E.M.

\section{RESULTS}

\section{Experiment 1. Occupation/activation of type I and type II} receptors in stress and no stress conditions in hippocampus, other brain regions, and pituitary

In order to investigate the hormonal conditions under which type I and type II receptors are occupied in vivo by endogenous glucocorticoids, we used saturation analysis to compare receptor binding in the hippocampus of 3 treatment groups: ADX, intact/no-stress and intact/ stress (Table $\mathrm{I}$ ). Using values from the $16 \mathrm{~h}$ ADX rats as a reference, the $B_{\max }$ for type II receptor binding was about $20 \%$ lower in the hippocampus of the intact/ no-stress rats, with no change in $K_{\mathrm{d}}$. The intact/stress rats had about a $40 \%$ lower $B_{\max }$ and a 5 times greater $K_{\mathrm{d}}$.

The presence of endogenous glucocorticoid had a greater effect on the type I receptor measures. In none of the intact/stress rat samples was there enough of a type I signal to perform a Scatchard analysis. Interestingly, for the intact/no-stress rats there was a variable type I signal. On two occasions there was no signal, whereas on the other there was a small signal with a $B_{\max }$ about $20 \%$ of that for the $16 \mathrm{~h} \mathrm{ADX}$ group.

The stress used in this first experiment, i.e., transporting rats from their home cage to a separate room for sacrifice $30 \mathrm{~min}$ later, produced a rise in serum CORT levels of $40.5 \pm 6.5 \mu \mathrm{g} \%$ compared to an average level of $3.6 \pm 1.1 \mu \mathrm{g} \%$ for the intact/no-stress group. On one occasion we split the pool of hippocampal cytosol obtained from intact/stress rats and filtered half of the 


\section{TABLE I}

Glucocorticoid receptor binding (mean \pm S.E.M.) of hippocampal cytosol from $16 \mathrm{~h} \mathrm{ADX}$ or intact rats with or without stress

Hippocampi were pooled from 3 rats for each treatment group and the mean and S.E.M. represent the results from 3 separate experiments. Type I binding was measured with $\left[{ }^{3} \mathrm{H}\right] \mathrm{DEX}(1-30 \mathrm{nM})$ in the presence of RU26988 $(0.5 \mu \mathrm{M})$, and non-specific type I binding was determined from $\left[{ }^{3} \mathrm{H}\right] \mathrm{DEX}$ binding in the presence of an excess of CORT $(2.5 \mu \mathrm{M})$. Type II binding was measured with $\left[{ }^{3} \mathrm{H}\right] \mathrm{DEX}$ (1-30 nM) with or without the presence of RU26988 $(0.5 \mu \mathrm{M})$. n.d., not detectable.

\begin{tabular}{|c|c|c|c|c|}
\hline \multirow[t]{2}{*}{ Treatment } & \multicolumn{2}{|c|}{ Type I binding } & \multicolumn{2}{|c|}{ Type II binding } \\
\hline & $\begin{array}{l}K_{d} \\
(n M)\end{array}$ & $\begin{array}{l}B^{\max } \\
(f \operatorname{mol} / m g)\end{array}$ & $\begin{array}{l}K_{d} \\
(n M)\end{array}$ & $\begin{array}{l}B_{\max } \\
\text { (fmol/mg) }\end{array}$ \\
\hline $\begin{array}{l}\text { ADX } \\
\text { Intact/ }\end{array}$ & $1.42 \pm 0.22$ & $103.7 \pm 23.6$ & $0.50 \pm 0.10$ & $259.8 \pm 36.8$ \\
\hline no-stress & - & $6.7 \pm 6.7^{* *}$ & $0.40 \pm 0.12$ & $177.7 \pm 9.5^{*}$ \\
\hline
\end{tabular}

${ }^{*} P<0.05,{ }^{* *} P<0.01$ for significant difference from ADX group, Newman-Keuls test

cytosol through an LH-20 Sephadex column in an effort to strip the unbound endogenous corticosteroid from the cytosol prior to use in the exchange assay. As shown in Fig. 1, this procedure reduced the $K_{\mathrm{d}}$ for the type II receptor by $50 \%$ without affecting the $B_{\max }$, indicating

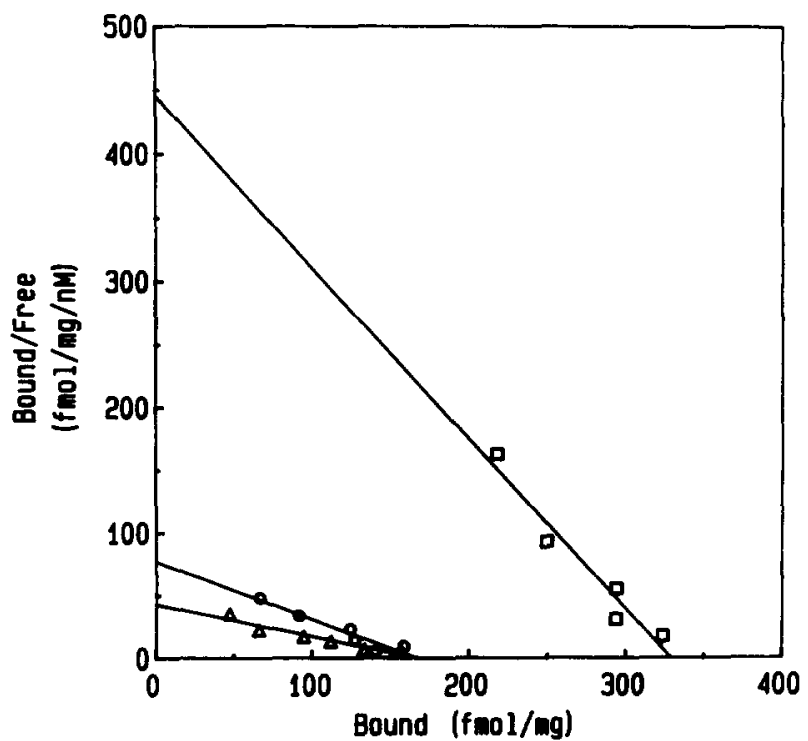

Fig. 1. Effect of Sephadex filtration of hippocampal cytosol from acute stressed rats on type II glucocorticoid receptor binding. Type II specific binding was measured with $\left[{ }^{3} \mathrm{H}\right] \mathrm{DEX}(0.3-30 \mathrm{nM})$. Type II binding of $16 \mathrm{~h} \mathrm{ADX}$ rats (open square) is compared to intact/stress rats. Cytosol from the intact/stress rats was divided in half. One fraction (open circle) was filtered through a Sephadex LH-20 column prior to incubation with $\left[{ }^{3} \mathrm{H}\right] \mathrm{DEX}$; the other fraction (open triangle) was placed directly into the incubation tubes. Note the ability of the Sephadex filtration to reduce the $K_{\mathrm{d}}$ (increase the slope) of the type II binding for the intact/stress rats towards that of the ADX rats, without altering the $B_{\max }$ ( $X$-intercept).

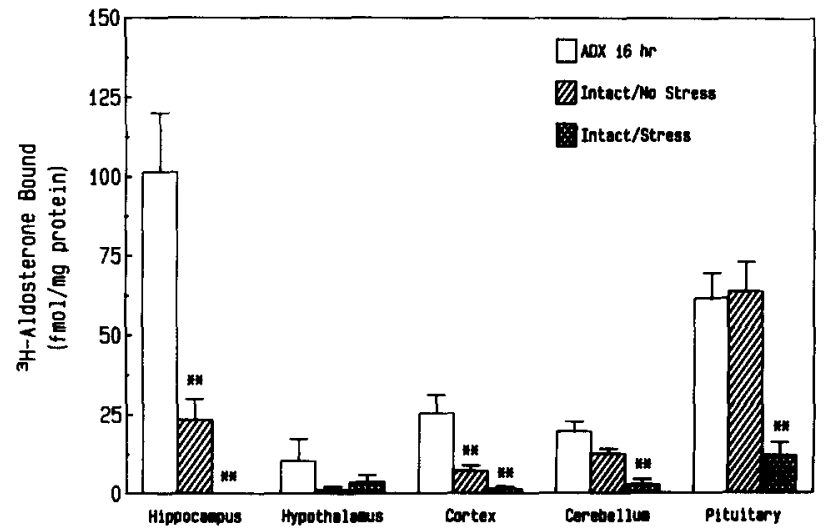

Fig. 2. Brain region and pituitary comparison of type I binding of ADX rats and intact stressed and unstressed rats. Type I binding for the hypothalamus, cortex, cerebellum and pituitary was measured with a single saturating concentration of $\left[{ }^{3} \mathrm{H}\right]$ aldosterone $(6 \mathrm{nM})$ in the presence of RU26988 $(0.5 \mu \mathrm{M}), n=4-6$. The hippocampal binding shown is the combined $B_{\max }$ values from Expts. 1, 2 and 4 (see Tables I-III) for the 3 treatment groups, $n=7 .{ }^{*} P<0.01$, significantly different from the ADX group for the same tissue area, Tukey test.

that the elevation in $K_{\mathrm{d}}$ was a result of the presence of competing steroid rather than an intrinsic change in receptor affinity. There was no measurable type I binding for either fraction of cytosol.

Other brain areas and the pituitary were investigated using single point binding assays for type I and type II receptors. In most cases there was a small, but detectable, type I signal for the intact/no-stress rats, and sometimes for the intact/stress rats. There was a significant decrease in cortical type I binding for the intact/ no-stress group compared to ADX levels and a decrease

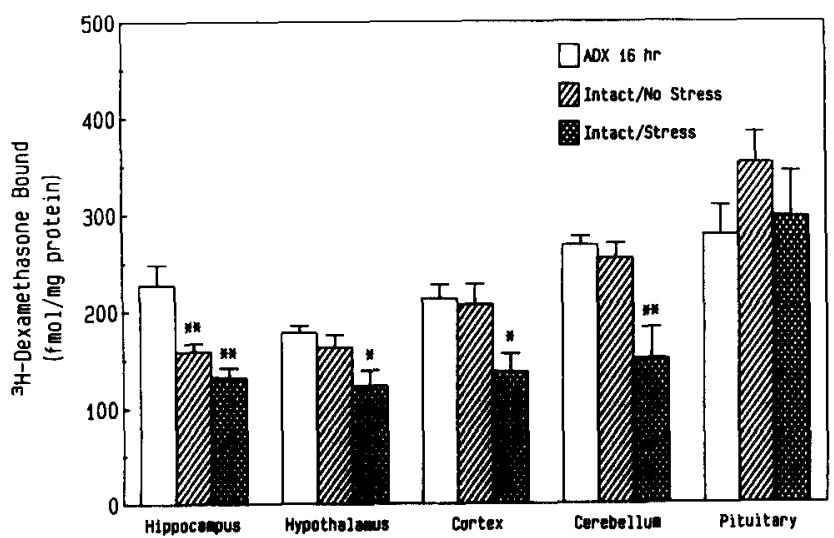

Fig. 3. Brain region and pituitary comparison of type II binding of ADX rats and intact stressed and unstressed rats. Type II binding for the hypothalamus, cortex, cerebellum and pituitary was measured with a single saturating concentration of $\left[{ }^{3} \mathrm{H}\right] \mathrm{DEX}(10 \mathrm{nM})$ with or without the presence of RU26988 $(0.5 \mu \mathrm{M}), n=4-6$. The hippocampal binding shown is the combined $B_{\max }$ values from Expts. 1, 2 and 4 (see Tables I, II and IV) for the 3 treatment groups, $n=7 .{ }^{*} P<0.05,{ }^{* *} P<0.01$, significantly different from the ADX group for the same tissue area, Tukey test. 


\section{TABLE II}

Effect of low dose dexamethasone treatment (mean \pm S.E.M.) on hippocampal glucocorticoid receptor binding of intact and ADX rats

Hippocampi were pooled from 3 rats for each treatment group and the mean and S.E.M. represent the results from 3 separate experiments. On each occasion type I binding was measured with $\left[{ }^{3} \mathrm{H}\right] \mathrm{DEX}(0.3-10 \mathrm{nM})$ or $\left[{ }^{3} \mathrm{H}\right]$ aldosterone (ALDO, $\left.0.3-6 \mathrm{nM}\right)$ in the presence of RU26988 (0.5 $\mu \mathrm{M})$. Non-specific binding was determined from $\left[{ }^{3} \mathrm{H}\right] \mathrm{DEX}$ or $\left[{ }^{3} \mathrm{H}\right]$ aldosterone binding in the presence of an excess of corticosterone $(2.5 \mu \mathrm{M})$. Type II binding was measured with $\left[{ }^{3} \mathrm{H}\right] \mathrm{DEX}(0.3-10 \mathrm{nM})$ with or without the presence of RU26988 $(0.5 \mu \mathrm{M})$. n.d., not detectable.

\begin{tabular}{|c|c|c|c|c|c|c|c|c|c|}
\hline Treatment & \multicolumn{3}{|c|}{ Type I ( $\left.{ }^{3} H\right]$ dex $)$} & \multicolumn{3}{|c|}{ Type I ( $\left[^{3}\right.$ H]aldo $)$} & \multicolumn{3}{|l|}{ Type II } \\
\hline $\mathrm{ADX} / \mathrm{DEX}$ & $1.89 \pm 0.51$ & $87.6 \pm 9.2$ & $137.8 \pm 40.3$ & $0.56 \pm 0.09$ & $92.9 \pm 15.2$ & $102.1 \pm 18.7$ & $0.40 \pm 0.04$ & $122.1 \pm 7.8^{*}$ & $63.6 \pm 6.1$ \\
\hline Intact/DEX & $1.93 \pm 0.26$ & $42.1 \pm 3.7$ & $67.2 \pm 19.2$ & $0.65 \pm 0.07$ & $47.3 \pm 3.3$ & $54.9 \pm 14.7$ & $0.47 \pm 0.08$ & $116.2 \pm 1.4^{*}$ & $61.5 \pm 8.5$ \\
\hline Intact/stress & n.d. & n.d. & 0 & n.d. & n.d. & 0 & $4.16 \pm 0.70^{* *}$ & $112.8 \pm 11.1^{*}$ & $58.4 \pm 5.0$ \\
\hline
\end{tabular}

${ }^{*} P<0.05,{ }^{* *} P<0.01$ for significant difference from ADX group, Newman-Keuls test $(n=3)$.

in both cortical and cerebellar type I binding for the intact/stress group (Fig. 2). There was a very low level of type I binding in the hypothalamus for all 3 treatment groups. Type II binding of the hypothalamus, cortex and cerebellum, in contrast to the hippocampus, exhibited a decrease in binding only for the intact/stress group (Fig. 3 ). The pituitary was especially insensitive to the presence of endogenous steroid. The only decrease in pituitary binding was for type I binding in the intact/stress rats.
Experiment 2. Effects of brief exposure to DEX on type $I$ and type II receptor binding

DEX is an effective agent for suppressing endogenous glucocorticoid and at the same time shows no significant labeling of type I receptors in vivo ${ }^{29}$. Therefore we used treatment of intact rats with DEX in the drinking water in an attempt to reveal more type I receptor binding than is evident in the intact/no-stress condition.

ADX and intact rats were given DEX $(1.5 \mu \mathrm{g} / \mathrm{ml})$ in the drinking water for one night prior to sacrifice. As
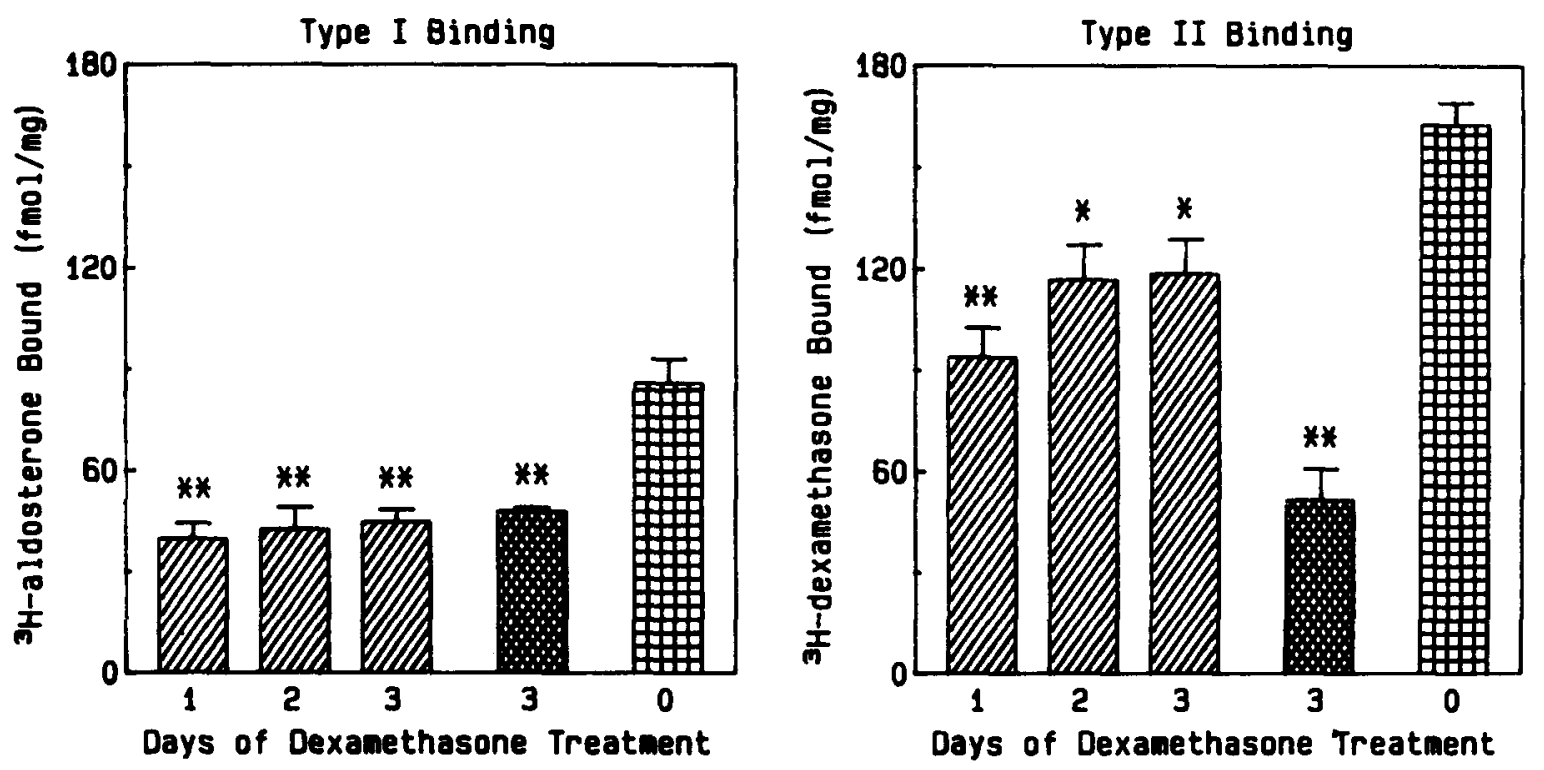

ZIntact + DeX (1 ag/ol)

Intact + DEX $15 \mathrm{mg} / \mathrm{nll}$ 田 $10 \mathrm{X}$

Fig. 4. Time and dose effect of DEX in the drinking water on hippocampal type I and type II binding. Type I binding on individual hippocampi was measured with $\left[{ }^{3} \mathrm{H}\right.$ ]aldosterone $(6 \mathrm{nM})$ in the presence of RU26988 $(0.5 \mu \mathrm{M})$; type II binding was measured with [ $\left.{ }^{3} \mathrm{H}\right] \mathrm{DEX}(10 \mathrm{nM}), n$ $=3-4 .{ }^{*} P<0.05,{ }^{* *} P<0.01$, significantly different from the ADX group, Tukey test. 
shown in Table II, DEX treatment had no effect on the $B_{\max }$ of hippocampal type I receptor binding of ADX rats, and elevated the $B_{\max }$ of intact rats to a level which was not significantly different from ADX rats. It should be noted that, in contrast to the first experiment, each replication of this experiment revealed a detectable type I signal for the intact/no-stress rats ranging from $25 \%$ to $38 \%$ of $\mathrm{ADX}$ levels. Again, however, there was no detectable type I signal for intact/stress rats. $K_{\mathrm{d}}$ values for type I binding were elevated in the intact/no-stress condition compared to intact/DEX and ADX groups. The type I binding levels and relative changes in $K_{\mathrm{d}}$ were similar whether $\left[{ }^{3} \mathrm{H}\right] \mathrm{DEX}$ or $\left[{ }^{3} \mathrm{H}\right]$ aldosterone were used to label type I binding, confirming the adequacy of [ $\left.{ }^{3} \mathrm{H}\right] \mathrm{DEX}$ to measure type I binding in vitro.

For type II receptors, overnight DEX $(1.5 \mu \mathrm{g} / \mathrm{ml})$ in the drinking water depressed the hippocampal $B_{\max }$ values in both ADX and intact animals, without altering the $K_{\mathrm{d}}$ values (Table II). Again, stress reduced the type II $B_{\max }$ compared to $16 \mathrm{~h} \mathrm{ADX}$ and it increased the $K_{\mathrm{d}}$ value significantly, indicating substantial competition by unlabeled glucocorticoid in the cytosol.

There was no significant difference between the serum CORT levels in the trunk blood of the intact/DEX rats $(0.6 \pm 0.1 \mu \mathrm{g} \%)$ and the intact/no-stress rats $(2.5 \pm 1.4$ $\mu \mathrm{g} \%)$. One hour of restraint stress prior to sacrifice produced a large increase in the serum CORT level (28.4 $\pm 3.4 \mu \mathrm{g} \%)$.

Experiment 3. Time course and dose response of $D E X$ treatment on type I and type II receptor binding

In order to investigate further the effects of DEX, different times and doses of exposure were utilized. Using single point binding assays, type I receptor binding was constant across the two doses and duration of DEX treatment, and was lower than in $16 \mathrm{~h} \mathrm{ADX}$ hippocam- pus (Fig. 4). In contrast, there was about a $30 \%$ decrease in type II binding of intact rats that had DEX $(1 \mu \mathrm{g} / \mathrm{ml})$ in their drinking water for 1, 2 or 3 days (Fig. 4) and a significantly greater decrease $(70 \%)$ with a higher dose of $\operatorname{DEX}(5 \mu \mathrm{g} / \mathrm{ml})$ in the drinking water for 3 days.

Experiment 4. Estimates of effect of stress and DEX on type I and type II receptor occupation and activation

Overnight access to a dose of DEX $(15 \mu \mathrm{g} / \mathrm{ml})$ in the drinking water ( 10 times higher than the dose used in the second experiment) produced an almost $90 \%$ decrease in the $B_{\max }$ for type II hippocampal binding of intact/ high-DEX rats or ADX/high-DEX rats, and about a 6-fold increase in $K_{\mathrm{d}}$, relative to ADX rats (Table III). Although the high dose of DEX produced a $20 \%$ decrease in the type I $B_{\max }$ of ADX/high-DEX rats, DEX treatment of intact rats resulted in an elevated type I $B_{\max }$ compared to the intact/no-stress rats (Table IV), as was also the case in the second experiment. This high dose of DEX, in contrast to the lower dose used in Expt. 2, produced a 3- to 4-fold increase in the type I $K_{\mathrm{d}}$, indicating significant competitive interaction of the exogenous steroid with the type I site in vitro.

We were intrigued by the small effect of the high dose of in vivo DEX treatment on type I binding level in spite of the large shift it produced in vitro on the type $I K_{\mathrm{d}}$. Similarly, we noted that in vivo stress levels of CORT produced only a $50 \%$ decrease in type II binding compared to $16 \mathrm{~h} \mathrm{ADX,} \mathrm{while} \mathrm{elevating} \mathrm{the} \mathrm{type} \mathrm{II} K_{\mathrm{d}}$ in vitro by more than 10 fold. We calculated estimates of the concentrations of endogenous CORT remaining in the cytosol of intact/no-stress and intact/stress rats and of exogenous DEX in the cytosol of ADX/high DEX rats. For enzyme-substrate interactions the presence of a competitive inhibitor increases the measured $K_{\mathrm{d}}$ by the factor of:

\section{TABLE III}

Comparison of change in hippocampal type II binding with hypothetical receptor occupancy by corticosterone or dexamethasone

Type II binding was measured with $\left[{ }^{3} \mathrm{H}\right] \mathrm{DEX}(0.3-10 \mathrm{nM})$ with or without the presence of RU26988 $(0.5 \mu \mathrm{M})$. See Results for the equations and their description used to estimate the concentration of DEX or corticosterone (CORT) in the cytosol and the percent occupancy of each. The $K_{\mathrm{dcomp}}$ used for estimating the concentration of DEX was the $K_{\mathrm{d}}$ value obtained for [ $\left.{ }^{3} \mathrm{H}\right] \mathrm{DEX}$ type II binding in the cytosol from ADX rats $(0.39$ $\mathrm{nM}$ ). The same value was used for the $K_{\mathrm{d} \text { lig }}$. The $K_{\mathrm{dcomp}}$ used for estimating the concentration of CORT was $0.5 \mathrm{nM}$ based on the type II value for CORT reported by others ${ }^{27}$.

\begin{tabular}{|c|c|c|c|c|c|c|}
\hline \multirow[t]{2}{*}{ Treatment } & \multicolumn{3}{|c|}{ Receptor binding values } & \multicolumn{3}{|c|}{ Estimated receptor occupancy } \\
\hline & $\begin{array}{l}K_{d_{o b r}} \\
(n M)\end{array}$ & $\begin{array}{l}B_{\max } \\
\text { (fmollmg) }\end{array}$ & $\begin{array}{l}\text { \% decrease of } \\
A D X B_{\max }\end{array}$ & $\begin{array}{l}\text { In vivo } \\
\text { competitor }\end{array}$ & $\begin{array}{l}\text { [comp] } \\
(n M)\end{array}$ & \%occupancy \\
\hline ADX & 0.39 & 223.4 & 0 & none & 0 & 0 \\
\hline ADX/high-DEX & 2.31 & 28.7 & 87.2 & DEX & 1.9 & 83.1 \\
\hline Intact/no-stress & 0.56 & 150.1 & 32.8 & CORT & 1.3 & 30.2 \\
\hline Intact/high-DEX & 2.45 & 25.5 & 88.6 & CORT + DEX & \multicolumn{2}{|c|}{ insufficient information } \\
\hline Intact/stress & 4.27 & 112.4 & 49.7 & CORT & 29.8 & 90.8 \\
\hline
\end{tabular}


$1+\left([\mathrm{comp}] / K_{\mathrm{dcomp}}\right)$

where [comp] is the concentration of the competitor and $K_{\text {dcomp }}$ is the dissociation constant for the competitor ${ }^{8}$. Applying this to ligand-receptor interactions we estimated the concentration of competing steroid present in the cytosol using the equation:

$K_{\text {dobt }}=K_{\text {dlig }}\left(1+\left([\right.\right.$ comp $\left.\left.] / K_{\text {dcomp }}\right)\right)$

and solving for [comp]:

[comp $]=\left(K_{\mathrm{dobt}} \cdot K_{\mathrm{dcomp}} / K_{\mathrm{dlig}}\right)-K_{\mathrm{dcomp}}$

where $K_{\mathrm{dobt}}$ was the $K_{\mathrm{d}}$ obtained from the saturation binding assay for the treatment group of interest, $K_{\text {dlig }}$ was the $K_{\mathrm{d}}$ for the radiolabeled ligand obtained from the saturation binding of the ADX group (in which no competing ligand was assumed to be present), and $K_{\mathrm{dcomp}}$ was the $K_{\mathrm{d}}$ of the competitor for the binding site.

We also estimated the percent occupancy of binding sites by the derived steroid concentrations. The percent of binding sites that would be occupied (Bound $/ B_{\max }$ ) by the estimated concentration of steroid was computed using the classic mass action law for enzyme-substrate interactions which has been adapted to receptor-ligand interactions ${ }^{43}$; the equation is:

Bound $=B_{\max }[$ steroid $] /\left(K_{\mathrm{d}}+[\right.$ steroid $\left.]\right)$

and by rearranging, percent of total binding is:

Bound $/ B_{\max }=[$ steroid $] /\left(K_{\mathrm{d}}+[\right.$ steroid $\left.]\right)$

where [steroid] was the estimated concentration of either
CORT or DEX and $K_{\mathrm{d}}$ was the respective $K_{\mathrm{d}}$ of each steroid for the type I and type II binding sites.

Thus, we obtained an estimate of the percent of receptors which were occupied in vivo by CORT in the intact rats or by DEX in the ADX/DEX rats. This estimate presumes that the steroid concentration in the cytosol was similar to that present intracellularly in vivo. The steroid concentration in the cytosol, however, is likely to be less than that present in vivo due to the dilution of tissue with buffer for homogenization. We compared the receptor occupancy estimates with the decreases in $B_{\max }$ for the respective treatment groups relative to $16 \mathrm{~h} A D X$ as measured with the binding assay. If all of the receptors which were occupied in vivo were also activated (and thus unavailable for exchange in the in vitro binding assay) then the estimates of percent in vivo occupancy by steroid should approximate the measured percent decrease in receptor binding. We also assumed that the presence of molybdate in the homogenization and incubation buffer prevented activation of receptors in vitro ${ }^{10}$.

Estimates of the concentration of endogenous CORT in the cytosol from intact/no-stress rats, based on the shift in the type I and type II receptor $K_{\mathrm{d}} \mathrm{s}$, was $1.8 \mathrm{nM}$ and $1.3 \mathrm{nM}$, respectively. These concentrations of CORT were calculated to produce a $70.3 \%$ occupancy of the type I receptor and a $30.2 \%$ occupancy of the type II receptor (Tables III and IV). These estimates of receptor occupancy by low basal levels of CORT agree well with the obtained in vivo decrease in type I (74.9\%) and type II $(32.8 \%)$ binding of intact/no-stress rats. The high concentration of CORT found in the intact/stress rats' cytosol, however, was estimated to be a concentration of steroid $(29.8 \mathrm{nM}$ ) sufficient to occupy $90.8 \%$ of the type II receptors, but this condition was associated with only

\section{TABLE IV}

\section{Comparison of change in hippocampal type I binding with hypothetical receptor occupancy by corticosterone or dexamethasone}

Type I binding was measured with either $\left[{ }^{3} \mathrm{H}\right] \mathrm{DEX}(0.3-10 \mathrm{nM})$ or $\left[{ }^{3} \mathrm{H}\right]$ aldosterone $(0.3-6 \mathrm{nM})$ in the presence of $\mathrm{RU} 26988(0.5 \mu \mathrm{M})$. Binding in the presence of corticosterone (CORT, $2.5 \mu \mathrm{M}$ ) was used to determine non-specific binding. Only type I binding measured with [ $\left.{ }^{3} \mathrm{H}\right]$ aldosterone is shown in this table. The concentration of DEX or corticosterone (CORT) ([comp]) in the cytosol and the percent occupancy was estimated using equations described in Results. The $K_{\text {dcomp }}$ used for estimating the concentration of DEX was the $K_{\mathrm{d}}$ value obtained for [ ${ }^{3} \mathrm{H}$ ]DEX type I binding in the cytosol from ADX rats $(0.93 \mathrm{nM})$. The $K_{\text {dcomp }}$ used for estimating the concentration of CORT was $3 \mathrm{nM}$ based on the type I $K_{\mathrm{d}}$ value for CORT reported by others ${ }^{27}$. The $K_{\text {dlig }}$ was the $K_{\mathrm{d}}$ value obtained for $\left[{ }^{3} \mathrm{H}\right]$ aldosterone type $I$ binding in the cytosol from ADX rats $(0.68 \mathrm{nM})$. n.d., not detectable.

\begin{tabular}{|c|c|c|c|c|c|c|}
\hline Treatment & \multicolumn{3}{|c|}{ Receptor binding values } & \multicolumn{3}{|c|}{ Estimated receptor occupancy } \\
\hline ADX/high-DEX & 2.26 & 85.0 & 20.8 & DEX & 2.2 & 70.3 \\
\hline Intact/no-stress & 3.10 & 26.9 & 74.9 & CORT & 1.8 & 78.3 \\
\hline Intact/high-DEX & 2.83 & 52.2 & 51.4 & CORT + DEX & \multicolumn{2}{|c|}{$\begin{array}{l}\text { insufficient information } \\
\text { insufficient information }\end{array}$} \\
\hline
\end{tabular}




\section{TABLE V}

\section{Uptake of ${ }^{3}$ HJcorticosterone in isolated nuclei}

$\left[{ }^{3} \mathrm{H}\right]$ Corticosterone (CORT, $150 \mu \mathrm{CI}$ ) was injected i.m. in ADX rats $1 \mathrm{~h}$ before sacrifice. Nuclei were isolated from brain tissue (see Methods) and protein extracted from nuclei with $0.6 \mathrm{M} \mathrm{KCl}$. After extraction of protein from the isolated nuclei the remaining $\left[{ }^{3} \mathrm{H}\right] \mathrm{CORT}$ in the nuclear pellet was extracted with ethanol, dried and counted in scintillation cocktail by a scintillation counter. Aliquots of the protein extract were placed directly in scintillation cocktail and radioactivity also counted. The amount of $\left[{ }^{3} \mathrm{H}\right] \mathrm{CORT}$ for the nuclear pellet reported in the table is the combined nuclear radioactivity content determined from the pellet ethanol extract and the protein extract.

\begin{tabular}{|c|c|c|c|c|}
\hline \multirow[t]{2}{*}{ Brain tissue } & \multicolumn{3}{|c|}{ Nuclear pellet } & \multirow{2}{*}{$\begin{array}{l}\text { Protein extract } \\
\left.{ }^{3} \mathrm{H}\right] \mathrm{CORT} \\
(\% \text { of pellet } \\
\text { (pm) }\end{array}$} \\
\hline & $\begin{array}{l}\text { DNA } \\
\text { content } \\
(m g)\end{array}$ & $\begin{array}{l}\% \text { of total } \\
\text { tissue } \\
\text { DNA } \\
\text { content }\end{array}$ & $\begin{array}{l}\left.{ }^{3} \mathrm{H}\right] \mathrm{CORT} \\
(\mathrm{cpm} / \mathrm{mg} \\
D N A\end{array}$ & \\
\hline Hippocampus & 0.045 & 25.7 & 11643 & 45.2 \\
\hline Amygdala & 0.023 & 16.5 & 8914 & 45.0 \\
\hline Cerebellum & 0.282 & 16.4 & 816 & 62.8 \\
\hline Cortex & 0.114 & 20.2 & 2198 & 62.9 \\
\hline Whole brain-1 & 0.789 & 20.1 & 2476 & 55.0 \\
\hline Whole brain-2 & 0.740 & 21.6 & 1946 & 52.0 \\
\hline
\end{tabular}

\section{a $49.7 \%$ decrease in binding.}

For DEX treatment there was a good accordance between the percent decrease in type II binding $(87.2 \%)$ and the estimated percent occupancy of type II binding sites $(83.1 \%)$ by the calculated concentration of exogenous DEX $(1.9 \mathrm{nM})$ present in the cytosol of ADX/ high-DEX rats (Table IV). On the other hand there was a poor correspondence in the two values for type I binding, in which there was a $20.8 \%$ decrease in binding while estimated levels of DEX $(2.2 \mathrm{nM})$ in the cytosol were sufficient to occupy $70.3 \%$ of the receptors (Table III).

Attempt to detect nuclear AS receptors by an exchange assay

Our data point to reduced cytosol type I and type II receptor availability when glucocorticoids are present in vivo. Because the destination of glucocorticoid bound receptors is the nucleus, we attempted to exchange nuclear receptors labelled with $\left[{ }^{3} \mathrm{H}\right] \mathrm{CORT}$ in vivo with cold CORT in vitro. We also attempted to label and exchange nuclear receptors with $\left[{ }^{3} \mathrm{H}\right] \mathrm{CORT}$ in the presence or absence of an excess of cold CORT in vitro.

Table $V$ shows the nuclear uptake of $\left[{ }^{3} \mathrm{H}\right] \mathrm{CORT}$ measured in different brain areas of rats injected with 150 $\mu \mathrm{Ci}\left[{ }^{3} \mathrm{H}\right] \mathrm{CORT}$ (i.m.) $1 \mathrm{~h}$ before sacrifice. In agreement with previous results ${ }^{20}$, the highest concentration of $\left[{ }^{3} \mathrm{H}\right] \mathrm{CORT}$ was found in the hippocampus and amygdala, and the lowest concentration in cerebellum, with intermediate levels in cortex or whole brain. Salt extraction
TABLE VI

Comparison of whole brain nuclear uptake of in vivo injection of $\left[^{3} \mathrm{H}\right]$ corticosterone with in vitro specific nuclear binding of $l^{3} \mathrm{HJ}$ corticosterone

Nuclei from rat brain were isolated as described in Methods and nuclear protein extracted with $0.6 \mathrm{M} \mathrm{KCl}$. Note the high amount of radioactivity in the protein extract from rats injected in vivo with 150 $\mu \mathrm{Ci}$ of $\left[{ }^{3} \mathrm{H}\right]$ corticosterone (CORT, $0.5 \mu \mathrm{g}$ ) compared to the variable and low in vitro specific binding of $\left[{ }^{3} \mathrm{H}\right] \mathrm{CORT}$ to protein extract from rats injected with vehicle, low dose or high dose of CORT $1 \mathrm{~h}$ before sacrifice $(n=3)$.

\begin{tabular}{lc}
\hline Treatment & $\begin{array}{c}\text { Protein extract radioactivity } \\
\text { (cpm/mg pellet DNA })\end{array}$ \\
\hline$\left[{ }^{3} \mathrm{H}\right] \mathrm{CORT}(150 \mu \mathrm{Ci})$ & $1208 \pm 334$ \\
Vehicle $(\mathrm{sesame} \mathrm{oil}, 1 \mathrm{mg} / \mathrm{kg})$ & $103 \pm 103$ \\
CORT $(0.5 \mu \mathrm{g})$ & $72 \pm 90$ \\
CORT $(50 \mathrm{mg} / \mathrm{kg})$ & $137 \pm 89$ \\
\hline
\end{tabular}

$(0.6 \mathrm{M} \mathrm{KCl})$ of soluble proteins from the nuclear pellet resulted in extraction of $45-60 \%$ of the total nuclear radioactivity. Salt extracts from nuclei isolated from whole brain were used for subsequent exchange assays. When filtering the nuclear salt extract from rats injected with $\left[{ }^{3} \mathrm{H}\right] \mathrm{CORT}$ through Sephadex LH-20 columns, $60-100 \%$ of the total salt extract radioactivity was recovered, in agreement with previous work ${ }^{18}$. Incubation of salt extract from rats injected with $\left[{ }^{3} \mathrm{H}\right] \mathrm{CORT}$ with an excess of unlabeled CORT $(2.5 \mu \mathrm{M})$ had no effect on the amount of radioactivity recovered from $\mathrm{LH}-20$ columns, indicating that most of the extracted radioactivity was macromolecularly bound, but could not be displaced by unlabeled CORT. There was also no evidence for specific binding of $\left[{ }^{3} \mathrm{H}\right] \mathrm{CORT}$ in the exchange assay with salt extract of nuclei isolated from ADX rats injected with either vehicle, low $(0.5 \mu \mathrm{g})$ or high $(50 \mathrm{mg} / \mathrm{kg})$ dose of unlabeled CORT $1 \mathrm{~h}$ before sacrifice (Table VI).

\section{DISCUSSION}

\section{Measurement of type I and type II receptors in relation to their activation}

These studies confirm that the presence of endogenous and/or exogenous glucocorticoids in brain tissue at the time the animal is sacrificed results in a lower level of AS receptor binding as measured in an in vitro cytosolic receptor binding exchange assay. The decrease in binding can be accounted for by the fact that AS receptors are unique compared to other steroid receptors. Steroid receptors bound to a steroid ligand become 'activated' to a form which binds more tightly to DNA enhancer elements ${ }^{40}$. Studies using cytosolic fractions have found that the activated form of the AS receptor, in contrast to 
other steroid receptors, is unable to exchange ligand in an in vitro binding assay ${ }^{9}$. Further evidence that this is a general property of the activated form of the AS receptor, not dependent on cellular compartmentalization, comes from our observation that AS receptors extracted from isolated nuclei of rat brain also did not participate in an exchange assay. Our experiments have utilized a long incubation duration $(20 \mathrm{~h})$ in order to maximize chances for exchange by unactivated receptors (see below). Thus, all AS receptors which are activated at the time the animal is sacrificed are unavailable for measurement in an in vitro binding assay. Therefore, the lower AS binding levels of intact rats relative to ADX rats reflect the proportion of the steady-state level of receptors that are activated at the time of cytosol preparation.

Taking advantage of this unique feature of AS receptors, we measured the amount of AS receptor binding in rats with varying levels of endogenous or exogenous glucocorticoids in order to make estimates of the proportion of AS receptor occupation and activation in various tissues during these conditions. We examined the degree of type I and type II AS receptor activation in the brains of non-ADX rats with low basal levels of circulating CORT and with high levels of CORT after acute stress. We found that the type I receptors in the hippocampus, hypothalamus and cortex were largely activated by low basal levels of CORT, whereas, there was not a significant activation of type $I$ receptors in the cerebellum or pituitary. The proportion of type I receptors activated in the hippocampus ranged from $60 \%$ to $100 \%$. The variability may reflect small fluctuations in the release of CORT even during low basal conditions. Moderate sized pulses of ACTH release during the nadir period of the ACTH and CORT circadian cycle have recently been described ${ }^{6}$. All of the type I receptors were activated in the hippocampus during acute stress, as were nearly all of the type I receptors in the other tissues.

There was much less activation of type II receptors during both basal and stress conditions. High circulating CORT levels arising from acute stress produced nearly a $50 \%$ activation of type II receptors in the various brain regions sampled, but interestingly, produced no activation of type II receptors in the pituitary. On the other hand, the hippocampus was the only tissue examined in which there was a significant activation of type II receptors under basal conditions. The apparent heightened sensitivity of the hippocampal AS receptors to circulating levels of CORT may partly account for the greater sensitivity of the hippocampus to the neurotrophic and neurotoxic effects of CORT as compared to other brain areas ${ }^{32,34}$.

A differential sensitivity between the hippocampus, other brain areas and the pituitary to the effect of CORT on AS binding levels was also observed by Brinton and $\mathrm{McEwen}^{4}$. As noted in their study, the insensitivity of the pituitary is most likely explained by the high concentration of CORT binding globulin (CBG) which is present in the pituitary ${ }^{16}$. CBG may have buffered the pituitary from the fluctuating levels of endogenous CORT, such that the concentration of free CORT at the receptor sites remained quite low. There is no evidence for a similar mechanism, however, within different brain regions, where CBG levels are believed to be uniformly low, so the differential sensitivity of the hippocampus remains a mystery.

An implication of the lack of type II receptor activation in the pituitary after acute stress is that in vivo the type II receptors of the pituitary may not participate in the negative feedback effect of CORT on ACTH release, contrary to what has been suggested based on in vitro studies $^{11}$. A role of type I receptors in vivo, however, cannot be ruled out.

Type $I$ and type $I$ receptor availability in relation to endogenous CORT levels

The proportion of hippocampal AS receptor activation during basal and acute stress conditions reported in this paper agree fairly well with estimates of AS receptor occupation under similar conditions as reported by others $^{21,27,29}$. The level of hippocampal type II binding we observed in the intact unstressed and stressed rats relative to that observed in $16 \mathrm{~h} \mathrm{ADX}$ rats is similar to the relative levels of total hippocampal AS receptor binding of intact stressed and unstressed rats compared to 12-14 h ADX rats as reported by Meaney et al. ${ }^{21}$. Two studies by Reul and de Kloet ${ }^{27}$ and Reul et al. ${ }^{29}$ also measured both type I and type II binding of intact unstressed and stressed rats. In one of the studies ${ }^{27}$ binding levels for intact rats were compared to levels from 3 day ADX rats. That study reported that intact unstressed and intact stressed rats had low levels of type I binding that were $10 \%$ and $2 \%$, respectively, of 3 day ADX levels. In the other study by the same group ${ }^{29}$, using binding levels from $24 \mathrm{~h} \mathrm{ADX}$ rats as a reference, the level of type I binding measured in intact unstressed rats was about $22 \%$ of the levels in ADX rats.

In both studies by Reul and de Kloet ${ }^{27}$ and by Reul et $\mathrm{al}^{29}$ the estimate of type II binding for intact stressed rats was about $25 \%$ of the binding for ADX rats, a lower estimate than obtained by us. The incubation duration used in the binding assay may be an important factor when there are high levels of competing steroid present in the tissue. In those two studies a $3 \mathbf{~ h}$ incubation period was used, whereas in our studies we used a $20 \mathrm{~h}$ incubation period. Meaney et al. ${ }^{21}$ report a substantial 
increase in total binding levels measured for intact stressed rats between $4 \mathrm{~h}$ and $20 \mathrm{~h}$ of incubation. They suggest, as have others ${ }^{13}$, that after only $4 \mathrm{~h}$ of incubation radiolabeled steroid has not had time to exchange with endogenous steroid and that the difference in binding obtained between $4 \mathrm{~h}$ and $20 \mathrm{~h}$ of incubation indicates the degree of receptor occupation, without activation, by endogenous steroid.

The proportion of type I receptors occupied/activated during basal levels is a point of interest because it has been proposed by others ${ }^{29}$ that the cell responds only to changes in type I receptor number, rather than to varying level of type I receptor occupation by steroid. This proposition was based on the assumption that the type I receptor is always at least $80 \%$ occupied by glucocorticoids. Our ability to detect type I receptor levels in intact rats during some conditions indicating as little as $35-45 \%$ occupation/activation suggests that the percent of type I receptor activation by steroid may, at some times, be meaningful.

It should be noted that our estimates of the percentage of receptors activated by glucocorticoids assumes that the difference in binding between non-ADX rats and rats that have been adrenalectomized for $16 \mathrm{~h}$ reflects only clearance of endogenous steroid and not any de novo upregulation of receptors. This is an assumption that has been supported by some data ${ }^{19,29}$ but proof of a lack of upregulation requires other techniques which can measure both activated and unactivated forms of the receptor. If there is some upregulation of adrenal steroid receptors within $16 \mathrm{~h}$ after ADX then the actual percent occupation/activation of receptors at the diurnal nadir could be considerably lower than our above estimates.

\section{Increased type I receptor availability with $D E X$ treatment}

Further evidence that the low level of type I binding that was measured in the intact unstressed rat was a result of receptor activation by low basal levels of endogenous glucocorticoids comes from the DEX treatment studies. Treatment of the rats with a low dose of DEX in the drinking water for one night resulted in a higher level of type I binding in the hippocampus than was measured in intact, unstressed rats. This increase in binding level was most likely a result of a lower level of endogenous steroid present in the tissue of the DEX treated rats as a result of the negative feedback effect of DEX on endogenous steroid levels. Scatchard analysis indicated that there was a considerable amount of endogenous steroid present in the hippocampal tissue from intact, unstressed rats which competed for radioligand binding in the in vitro binding assay, whereas there was no evidence of steroid competing for type I binding in the hippocampal tissue of rats receiving low dose DEX treatment.
Type I and type II receptor occupation and/or activation by CORT and DEX

Interestingly, DEX produced very little activation of the type I receptor in the hippocampus, even with the high dose treatment which resulted in some competition for type I binding in vitro. Thus, DEX has a high affinity for type I receptors in vitro (see Methods) but does not interact with the receptors in vivo in such a way as to cause their activation. On the other hand, DEX was very effective at activating the type II receptor. Scatchard analysis, which provided information about the presence of competing steroid as well as level of available receptors, indicated that the proportion of receptor occupation and activation may not have been identical. Although activation of the AS receptor is not instantaneous, the activation process is estimated to be fairly $\mathrm{rapid}^{24}$, so that the difference in receptor occupation and activation at the time of sacrifice probably was not simply a result of the lag in activation time. Based on the degree of shift in the $K_{\mathrm{d}}$ obtained for type I and type II binding of intact unstressed, intact stressed and ADX/high-DEX treated rats in our study, we estimated the concentration of endogenous CORT or exogenous DEX present in the cytosol. Then, using estimates of the type I and type II receptor $K_{\mathrm{d}}$ for CORT and DEX we computed the hypothetical percent of receptors that would be occupied in vivo by the derived steroid concentrations. The percent occupancy of type I and type II receptors by levels of CORT in intact unstressed rats and the percent occupancy of type II receptors by DEX levels in ADX/high-DEX rats corresponded closely to the percent decrease in binding levels found in those cases relative to $16 \mathrm{~h} \mathrm{ADX}$. On the other hand, two discrepancies became apparent: (1) stress levels of CORT were estimated to be of sufficient level in the cytosol to produce a $90 \%$ occupation of the type II receptor but produced in vivo only a $50 \%$ reduction in binding (i.e. 50\% activation); (2) DEX treatment of ADX rats was estimated to produce at least $86 \%$ occupation of the type I receptor based on cytosol DEX levels, but produced in vivo only a $21 \%$ reduction in binding (i.e. $21 \%$ activation).

These discrepancies suggest that there is a limited capacity for activation of the type II receptor by CORT and of the type 1 receptor by DEX. A greater efficiency of DEX compared to CORT in producing activation of AS receptors has also been noted in AtT- 20 cells, which contain only type II receptors ${ }^{37,38}$. Also, in thymus cells, DEX was found to produce a greater proportion of activated to unactivated AS receptors than was produced by $\mathrm{CORT}^{25}$. Munck and Holbrook propose that the different steady-state levels of activated to unactivated AS-receptor complexes is a result of a difference in the rate of dissociation of various hormones from the 
activated receptor rather than an inefficiency in the activation process ${ }^{25}$.

Several behavioral deficits resulting from ADX have been reported which were normalized with low doses of CORT treatment, but not DEX treatment, leading to the speculation that type I receptors were responsible for the CORT-specific actions ${ }^{15}$. The poor ability of DEX to produce or maintain activated type I receptors, in spite of its high affinity in vitro for type I receptors, may account for the ineffectiveness of DEX treatment in mediating effects dependent on type I receptor activity.

\section{Conclusion}

In summary, the hippocampus stands out as uniquely sensitive to the ability of low basal CORT levels to activate both type I and type II AS receptors. The proportion of type I receptors in the hippocampus which were unactivated or unoccupied by basal levels of CORT were, however, as measured in our study somewhat higher than has been reported by others. Furthermore, treatment with a low dose of DEX decreased the level of endogenous steroid present in the hippocampal tissue resulting in an increase in the number of unactivated type I receptors. This suggests that there may be a greater capacity for fluctuations in type I receptor occupation in vivo than had previously been suggested. AS receptors in the pituitary, in contrast to the hippocampus, were apparently largely buffered from changes in circulating levels of endogenous CORT. Even acute stress levels of glucocorticoids were unable to produce evidence for activation of type II receptors in the pituitary. Finally,

\section{REFERENCES}

1 Arriza, J.L., Weinberger, C., Cerelli, G., Glaser, T.M., Handelin, B.L., Housman, D.E. and Evans, R.M., Cloning of human mineralocorticoid receptor complementary DNA: structural and functional kinship with the glucocorticoid receptor, Science, 237 (1987) 268-275.

2 Beaumont, K. and Fanestil, D.D., Characterization of rat brain aldosterone receptors reveals high affinity for corticosterone, Endocrinology, 113 (1983) 2043-2051.

3 Bradford, M.M., A rapid and sensitive method for the quantitation of microgram quantities of protein utilizing the principle of protein-dye binding, Anal. Biochem., 72 (1976) 248-254.

4 Brinton, R.E. and McEwen, B.S., Regional distinctions in the regulation of type I and type II adrenal steroid receptors in the central nervous system, Neurosci. Res. Commun., 2 (1988) 37-45.

5 Burton, K., A study of the conditions and mechanisms of the diphenylamine reaction for the colorimetric estimation of deoxyribonucleic acid, Biochem. J., 62 (1956) 315-323.

6 Carnes, M., Lent, S., Feyzi, J. and Hazel, D., Plasma adrenocorticotropic hormone in the rat demonstrates three different rhythms within 24 h, Neuroendocrinology, 50 (1989) 17-25.

7 Chao, H.M., Choo, P.H. and McEwen, B.S., Glucocorticoid and mineralocorticoid receptor mRNA expression in rat brain, Neuroendocrinology, 50 (1989) 365-371. the degree of AS receptor occupation and activation may not always be identical. CORT was less efficient at activating the type II receptor than the type I receptor, such that at higher circulating levels there was apparently a $90 \%$ occupation of type II receptors in the hippocampus but only $50 \%$ activation. DEX, on the other hand, was much more efficient at activating the type II receptor than the type I receptor. This may account for the discrepancy between the high affinity of DEX for the type I receptor in vitro, and its apparent low efficacy as a type I agonist in vivo. This may also explain why DEX is a much more potent glucocorticoid than CORT, even though the in vitro affinity of DEX for the type II receptor is similar to that of CORT $^{26}$.

Although cytosolic AS receptor binding assays are limited by their ability to only measure the inactivated form of the receptor, levels of receptor binding measured 14-24 h after ADX may closely reflect the in vivo steady-state level of receptors present in the animal. Furthermore, our results illustrated that saturation binding studies, which provide information about the number of available binding sites and the potential concentration of steroid present at the binding sites in vivo, can assist in the evaluation of the state of AS receptors during different pharmacological treatments and physiological conditions.

Acknowledgements. We are grateful to Dr. Helen M. Chao and Dr. Andrew Miller for critical and constructive review of this manuscript. This work was supported by a NIAAA Postdoctoral Fellowship to R.L.S. (5 F32 AA05256), and NIH grants to E.A.Y. (NH 00427) and B.S.M (MH 41256).

8 Cheng, Y-C. and Prusoff, W.H., Relationship between the inhibition constant $\left(\mathrm{K}_{\mathrm{I}}\right)$ and the concentration of inhibitor which causes 50 per cent inhibition $\left(\mathrm{I}_{50}\right)$ of an enzymatic reaction, Biochem. Pharmacol., 22 (1973) 3099-3108.

9 Chou, Y.-C. and Luttge, W.G., Activated type II receptors in brain cannot rebind glucocorticoids: relationship to progesterone's antiglucocorticoid actions, Brain Research, 440 (1988) 67-78.

10 Dahmer, M.K., Housley, P.R. and Pratt, W.B., Effects of molybdate and endogenous inhibitors on steroid-receptor inactivation, transformation, and translation, Annu. Rev. Physiol, 46 (1984) 67-81.

11 Dayanithi, G. and Antoni, F.A., Rapid as well as delayed inhibitory effects of glucocorticoid hormones on pituitary adrenocorticotropic hormone release are mediated by type II glucocorticoid receptors and require newly synthesized messenger ribonucleic acid as well as protein, Endocrinology, 125 (1989) 308-313.

12 Gorski, J., The nature and development of steroid hormone receptors, Experientia, 42 (1986) 744-750.

13 Ho-Kim, M.A., Tremblay, R.R. and Dubé, J.Y., Determination of occupied cytoplasmic glucocorticoid receptor sites by an exchange assay in rat muscles, J. Steroid Biochem., 18 (1983) 179-184.

14 Hollenberg, S.M., Weinberger, C., Ong, E.S., Cerelli, G., Oro, A., Lebo, R., Thompson, E.B, Rosenfeld, M.G. and Evans, R.M., Primary structure and expression of a functional human 
glucocorticoid receptor cDNA, Nature (Lond.), 318 (1985) 635-641.

15 de Kloet, E.R. and Reul, J.M.H.M., Feedback action and tonic influence of corticosteroids on brain function: a concept arising from the heterogeneity of brain receptor systems, Psychoneuroendocrinology, 12 (1987) 83-105.

16 de Kloet, E. R., Burbach, P. and Mulder, G.H., Localization and role of transcortin-like molecules in the anterior pituitary, $\mathrm{Mol}$. Cell. Endocrinol., 7 (1977) 261-273.

17 Limbird, L.E., Cell Surface Receptors: a Short Course on Theory and Methods, Vol. 512, Nijhoff, Boston, 1986, pp. 394-401.

$18 \mathrm{McEwen}, \mathrm{B} . \mathrm{S}$. and Plapinger, L., Association of ${ }^{3} \mathrm{H}$ corticosterone-1,2 with macromolecules extracted from brain cell nuclei, Nature (lond.), 226 (1970) 263-265.

19 McEwen, B.S., Wallach, G. and Magnus, C., Corticosterone binding to hippocampus: immediate and delayed influences of the absence of adrenal secretion, Brain Research, 70 (1974) 321-334.

20 McEwen, B.S., Weiss, J.M. and Schwartz, L.S., Retention of corticosterone by cell nuclei from brain regions of adrenalectomized rats, Brain Research, 17 (1970) 471-482.

21 Meaney, M.J., Viau, V., Aitken, D.H. and Bhatnagar, S., Stress-induced occupancy and translocation of hippocampal glucocorticoid receptors, Brain Research, 445 (1988) 198-203.

22 Moguilewsky, M. and Raynaud, J.P., Evidence for a specific mineralocorticoid receptor in rat pituitary and brain, $J$. Steroid Biochem., 12 (1980) 309-314.

23 Munck, A. and Foley, R., Activated and non-activated glucocorticoid-receptor complexes in rat thymus cells: kinetics of formation and relation to steroid structure, J. Steroid Biochem., 12 (1980) 225-230.

24 Munck, A. and Foley, R., Activation of steroid hormonereceptor complexes in intact target cells in physiological conditions, Nature (Lond.), 278 (1979) 752-754.

25 Munck, A. and Holbrook, N.J., Glucocorticoid-receptor complexes in rat thymus cells. Rapid kinetic behavior and a cyclic model, J. Biol. Chem., 259 (1984) 820-831.

26 Munck, A., Guyre, P.M. and Holbrook, N.J., Physiological functions of glucocorticoids in stress and their relation to pharmacological actions, Endocr. Rev., 5 (1984) 25-44.

27 Reul, J.M.H.M. and de Kloet, E.R., Two receptor systems for corticosterone in rat brain: microdistribution and differential occupation, Endocrinology, 117 (1985) 2505-2511.

28 Reul, J.M.H.M., van den Bosch, F.R. and de Kloet, E.R., Differential response of type I and type II corticosteroid receptors to changes in plasma steroid level and circadian rhythmicity, Neuroendocrinology, 45 (1987) 407-412.

29 Reul, J.M.H.M., van den Bosch, F.R. and de Kloet, E.R.,
Relative occupation of type-I and type-II corticosteroid receptors in rat brain following stress and dexamethasone treatment: functional implications, J. Endocrinol., 115 (1987) 459-467.

30 Roy, E.J. and McEwen, B.S., An exchange assay for estrogen receptors in cell nuclei of the adult rat brain, Steroids, 30 (1977) 657-669.

31 Sapolsky, R.M., Krey, L.C. and McEwen, B.S., Corticosterone receptors decline in a site-specific manner in the aged rat brain, Brain Research, 289 (1983) 235-240.

32 Sapolsky, R.M., Krey, L.C. and McEwen, B.S., Prolonged glucocorticoid exposure reduces hippocampal neuron number: implications for aging, J. Neurosci., 5 (1985) 1222-1227.

33 Sapolsky, R.M., Krey, L.C. and McEwen, B.S., Stress downregulates corticosterone receptors in a site-specific manner in the brain, Endocrinology, 114 (1984) 287-292.

34 Sloviter, R.S., Valiquette, G., Abrams, G.M., Ronk, E.C., Sollas, A.L., Paul, L.A. and Neubort, S., Selective loss of hippocampal granule cells in the mature rat brain after adrenalectomy, Science, 243 (1989) 535-538.

35 Stephenson, G. and Funder, J., Hippocampal and renal type I receptors are differentially regulated, Am. J. Physiol., 252 (1987) E525-E529.

36 Sutanto, W. and de Kloet, E.R., Species-specificity of corticosteroid receptors in hamster and rat brains, Endocrinology, 121 (1987) 1405-1411.

37 Svec, F. Biopotency of corticosterone and dexamethasone in causing glucocorticoid receptor downregulation, J. Steroid Biochem., 23 (1985) 669-671.

38 Svec, F. and Harrison, R.W., The intracellular distribution of natural and synthetic glucocorticoids in the AtT-20 cell, Endocrinology, 104 (1979) 1563-1568.

39 Tornello, S., Orti, E., De Nicola, A.F., Rainbow, T.C. and McEwen, B.S., Regulation of glucocorticoid receptors in brain by corticosterone treatment of adrenalectomized rats, Neuroendocrinology, 35 (1982) 411-417.

40 Vanderbilt, J.N., Miesfeld, R., Maler, B.A. and Yamamoto, K.R., Intracellular receptor concentration limits glucocorticoiddependent enhancer activity, Mol. Endocrinol., 1 (1987) 68-74.

41 Veldhuis, H.D., van Koppen, C., van Ittersum, M. and de Kloet, E.R., Specificity of the adrenal steroid receptor system in rat hippocampus, Endocrinology, 110 (1982) 2044-2051.

42 Walters, M.R., Steroid hormone receptors and the nucleus, Endocr. Rev., 6 (1985) 512-543.

43 Yamamura, H.I., Enna, S.J. and Kuhar, M.J., Neurotransmitter Receptor Binding, Raven, New York, 1978.

44 Zigmond, R.E. and McEwen, B.S., Selective retention of oestradiol by cell nuclei in specific brain regions of the ovariectomized rat, J. Neurochem., 17 (1970) 889-899. 